\title{
Maturity and level of knowledge management in the company: an application of Nonaka and Takeuchi model and Fuzzy Logic
}

\author{
A maturidade e o nível de gestão de conhecimento na empresa: \\ uma aplicação do modelo de Nonaka e Takeuchi e a Lógica Fuzzy
}

\author{
Lídia Silveira Arantes $^{1}$ (D), Orlando Martinelli Junior ${ }^{2}$ (D), Thales de Oliveira Costa Viegas ${ }^{3}$ (D), \\ Júlio Eduardo Rohenkoh² (D) \\ ${ }^{1}$ Universidade Federal do Rio de Janeiro - UFRJ, Instituto de Economia, Programa de Pós-Graduação em \\ Economia, Rio de Janeiro, RJ, Brasil. E-mail: lidiaarantes@gmail.com \\ ${ }^{2}$ Universidade Federal de Santa Maria - UFSM, Departamento de Economia e Relações Internacionais, Santa \\ Maria, RS, Brasil. E-mail: orlando.martinelli@gmail.com; julioroh@gmail.com \\ ${ }^{3}$ Universidade Federal de Santa Maria - UFSM, Departamento de Economia, Santa Maria, RS, Brasil. E-mail: \\ thales.viegas@gmail.com
}

How to cite: Arantes, L. S., Martinelli Junior, O., Viegas, T. O. C., \& Rohenkoh, J. E. (2021). Maturity and level of knowledge management in the company: an application of Nonaka and Takeuchi model and Fuzzy Logic. Gestão \& Produção, 28(2), e5305. https://doi.org/10.1590/1806-9649-2020v28e5305

\begin{abstract}
This paper aims to understand how the interconnection between the tacit and explicit dimensions of knowledge impacts knowledge management and its degree of maturity. Knowledge management maturity is understood as the ability firms are expected to have in order to exercise (to some degree) the skills required to manage knowledge internally. Nonaka and Takeuchi (N\&T) model of organizational knowledge management was applied to a sample of companies (segmented by size) from the states of São Paulo, Minas Gerais, and Rio de Janeiro, by using the logic of fuzzy sets. The results have shown that small and medium companies have lower levels of knowledge management maturity when compared to large companies. However, in large companies, knowledge management is at medium levels. In this context, this paper suggests, as management guidelines, that companies measure their professionals' perception regarding the company level of knowledge management, pursuing to identify which of their components should be developed.
\end{abstract}

Keywords: Knowledge; Companies; Management; Fuzzy logic.

Resumo:O objetivo deste trabalho é compreender como a interconexão entre as dimensões (tácita e explícita) do conhecimento impacta na gestão de conhecimento e no seu grau de maturidade. Entende-se como maturidade da gestão de conhecimento a capacidade das firmas de exercitar (em algum grau) as competências necessárias para gerir o conhecimento internamente. O modelo de Nonaka e Takeuchi (N\&T) de gestão de conhecimento organizacional é aplicado para uma amostra de empresas (segmentadas por porte) dos estados de São Paulo, Minas Gerais e Rio de Janeiro, utilizando-se a lógica de conjuntos fuzzy. Os resultados mostram que as pequenas e médias empresas possuem graus maturidade de gestão de conhecimento menores se comparadas às grandes empresas. Entretanto, nas grandes empresas a gestão de conhecimento se encontra em patamares medianos. Neste contexto, este trabalho sugere, como

Received Feb. 17, 2019 - Accepted Aug. 21, 2019

Financial support: CNpq.

This is an Open Access article distributed under the terms of the Creative Commons Attribution License, which permits unrestricted use, distribution, and reproduction in any medium, provided the original work is properly cited. 
orientações gerenciais, que as empresas mensurem a percepção dos seus profissionais quanto ao seu nível de gestão do conhecimento, a fim de identificar quais de seus componentes devem ser desenvolvidos.

Palavras-chave: Conhecimento; Empresas; Gerenciamento; Lógica fuzzy.

\section{Introduction}

Heterodox theories advocate that the existence of heterogeneities between firms is associated with existing asymmetries in the dynamic creation of qualification related to organizational routines, technological resources for innovative processes, and business strategies. All of these aspects generally involve the creation, coordination, and management of intra-firm knowledge and learning, once they may impact companies' performance as a result of their competitive advantages (Nonaka et al., 1997; Leonardi \& Bastos, 2014).

Knowledge should not be conceived as a mere accumulation of information, even if all messages received by one's brain are compiled into a repository. Knowledge is best understood as a structure, or as a complex and free pattern, with its parts connected by ties of different degrees of synergy. While information is fragmented and transitory, knowledge is structured, coherent, and meaningful (Ancori et al., 2000). Coded information, however, could contribute to organizational and technological capabilities only if people can interpret them (Cowan et al., 2000).

Knowledge consists basically of two dimensions. Tacit knowledge, which is acquired by experience, is subjective, and difficult to be reproduced (Nonaka \& Takeuchi, 1995), while explicit knowledge, which has a codified nature, can be reproduced from training (qualifications), practices and simulations (e.g. airplane pilots and surgeries). Therefore, knowledge can be transferred and stored, as well as improve the efficiency of transactions, despite the costs involved in the process (Foray, 2007).

The relationship between codified and tacit knowledge is complementary and not substitute; that is, they are not necessarily separate entities. They interact and intersect with each other in the creative activities human beings perform (Nonaka et al., 1996; Ancori et al., 2000; Cowan et al., 2000), and also within companies in their different activities.

In order to be treated as an economic good, knowledge must be placed in an environment that allows it to circulate and to be exchanged (Ancori et al., 2000). The cognitive capacities individuals have (the feeling of similarity, sensitivity to external signals, or imagination) will strongly determine how knowledge is acquired and accumulated, as well as how it produces different meanings. Regarding this, knowledge processing is highly specific and personal (Ancori et al., 2000).

Even though there is a perception of knowledge as valuable to the firm, there are still bottlenecks concerning active management in organizations. There is a need for research and practical discussions on how knowledge can be managed and used most effectively in daily basis (Davenport \& Prusak, 1998). The business knowledge management corresponds to the ability companies have to perform processes of knowledge management in a higher or lower degree of complexity and effectiveness. Knowledge maturity, related to the management of different company activities, can be assessed by "valuation models" which provide companies with evidence of their degree of maturity and evolution associated with certain aspects of their knowledge management (Lin, 2007). 
The literature related to knowledge management uses the maturity concept to designate the level in which the company is regarding this management. What differs is the focus of the maturity assessment on each job and the variables and methodologies used to measure it. The present paper uses the Nonaka and Takeuchi (N\&T) theoretical model and the application of Fuzzy Logic.

Based on an empirical research carried out with industrial companies segmented by size, this paper aims to understand how the management of firms affects the interconnections between the dimensions of knowledge (tacit and explicit) in order to generate competitive capabilities and innovations in organizations.

The definition, systematization, and measurement of organizational knowledge can allow the company management to transform these intangible assets (knowledge and learning) into strategic assets (Nelson \& Winter, 1982), which represents a fundamental source of generating dynamic competitive advantages (Nonaka \& Takeuchi, 1995).

Beyond this introduction, this paper has been organized into five further sections. In the second section, the N\&T knowledge conversion model is presented, and its empirical application is detailed with different forms of measurement; in the third section, the methodology is explained with measurement based on Fuzzy Logic; in the fourth, the main results are presented and discussed; Finally, the conclusions of this study are pointed out.

\section{Nonaka and Takeuchi's knowledge conversion model (N\&T)}

The first studies on the topic "creation of organizational knowledge" appeared in the late 1980s. Since then, the conception of knowledge has been refined and discussed by several researchers on the subject. Nonaka et al. (1997) understand that the process of knowledge creation is possible due to two dimensions, one epistemological and the ontological. In the epistemological dimension, there are the tacit and the explicit knowledges, while in the ontological dimension, the level of knowledge varies from individual to interorganizational, through the group and the organization. There is the perspective that knowledge is not private, but social, so obtaining knowledge by the individual is only possible through contact with new experiences. Factors, such as the possibility of creation, learning, and the recognition of the new are phenomena that are fundamental to the process of creating cognitive processes, and can lead to innovations (Leonardi \& Bastos, 2014). Personal knowledge emerges from the combination of information, interpretation, reflection, and experience in a particular situation. Therefore, it is necessary to understand the organizational processes through which companies access and use the knowledge possessed by their members.

Nonaka \& Takeuchi (1995) propose that the acquired knowledge needs to be "widely" shared in organizations, stored and used for the development of new technologies and products (Soo et al., 2002). To create organizational knowledge, personal (explicit and tacit) knowledge must be externalized and/or shared.

\subsection{The knowledge spiral}

According to Nonaka et al. (1996) there are four patterns of knowledge conversion: socialization, externalization, combination, and internalization. Knowledge amplifies in an increasing spiral as it moves from the individual to the organizational levels. Therefore, the set of those four forms is called the knowledge spiral. Socialization is 
an experience-sharing process that is capable of creating tacit knowledge, such as the formation of mental models and technical skills that can be shared. All individuals can acquire tacit knowledge directly from others without necessarily using verbal language. An example of this can be seen by learners (in handcrafts or other artifacts) who learn through observation, imitation, and practice by working with their masters.

The second model of knowledge conversion, known as externalization, is a process of articulating tacit into explicit knowledge. It is a mechanism of knowledge creation by excellence, as knowledge uses metaphors, analogies, concepts, hypotheses, or models. The third form of knowledge conversion is called combination, and it is presented as a process of systematization of concepts with regards to knowledge. This conversion involves the articulation of different forms of explicit knowledge. Individuals exchange and combine knowledge through the means available in the firm, such as documents, meetings, telephone conversations, or computer communication networks.

The fourth and final form of conversion is called internalization and corresponds to a process of incorporating explicit knowledge into tacit knowledge, which is closely related to "learning by doing". The internalization depends on experiences based on shared mental models. In order to convert explicit knowledge into tacit knowledge, the production of documents or oral method is effective (as in speech and in lectures). Documentation allows to express experiences and improve tacit knowledge (Darroch, 2003).

To be internalized, explicit knowledge can be formalized, verbalized, as well as diagrammed into documents, manuals, or oral narrative. Also, documents or manuals facilitate the sharing of explicit knowledge with others, helping them to live others' experiences indirectly (i.e., "re-experimenting" them). Those modes of knowledge conversion discussed are shown in Figure 1.

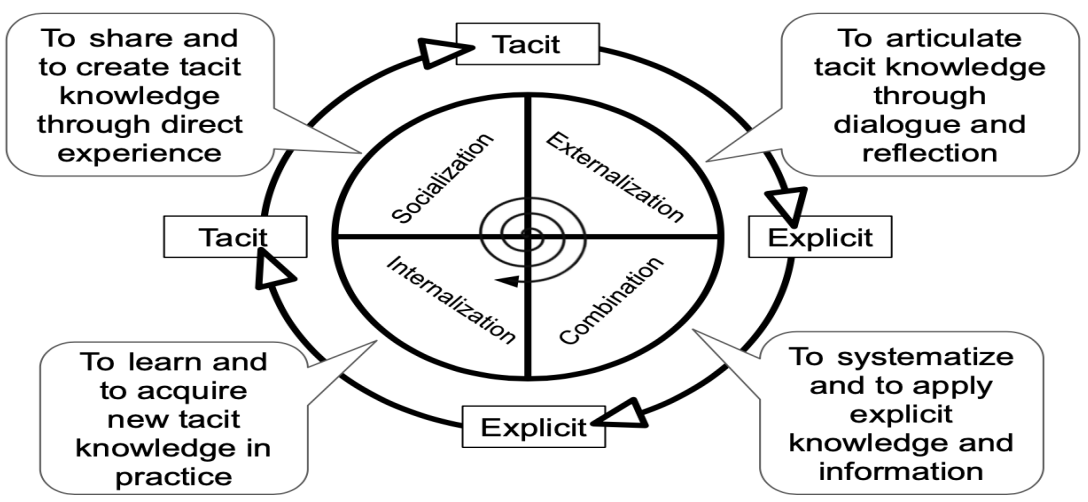

Figure 1. The knowledge spiral. Source: Nonaka \& Takeuchi (2008).

The company's behavior can be explained by the way it deals with knowledge, taking into account the belief that the firm not only "processes" that, but also creates it (Nonaka et al., 1997). For instance, innovation, which is a key form of organizational knowledge creation, cannot be sufficiently explained in terms of information processing or problem solving. In the process of absorbing new knowledge, the individual has a central role, since ideas are formed in their minds, and interaction between individuals often plays a critical role in the development and improvement of those ideas. That is, "communities of interaction" contribute to the expansion and development of new 
knowledge (Nonaka, 1994). Additionally, the study by Nonaka and Takeuchi highlights the importance of reflecting on the knowledge that emerges from the complex relationships established in the companies. Companies are in a privileged economic context in terms of providing, developing and assimilating knowledge (Tatto \& Bordin, 2016).

\subsection{Studies concerning the empirical application of Nonaka and Takeuchi model}

Firstly, as a matter of exemplifying the researches on the empirical applications of this model, five papers containing at their core the measurement of organizational knowledge management, are presented, as well as their distinct methodological bases, and main results that are congruent with the research efforts of this article. Subsequently, there are six more papers described, to highlight the continued use of Nonaka and Takeuchi's work in modern studies, emphasizing its relevance as a theoretical background. It is noteworthy that all the mentioned studies reflect distinct contexts and realities, and show how flexible and adaptable to different realities the model is, once it presents itself as a multidisciplinary issue.

Table 1. Empirical examples of the N\&T knowledge conversion model.

\begin{tabular}{|c|c|c|c|}
\hline $\begin{array}{l}\text { AUTHOR; YEAR } \\
\text { AND WORK }\end{array}$ & AIMS & $\begin{array}{l}\text { METHOD AND } \\
\text { JUSTIFICATION }\end{array}$ & RESULTS \\
\hline $\begin{array}{l}\text { Nonaka et al. } \\
\text { (1994) }\end{array}$ & \multirow{2}{*}{$\begin{array}{l}\text { To build up and } \\
\text { test a knowledge } \\
\text { creation model } \\
\text { from Nonaka's } \\
\text { theory (1994). }\end{array}$} & $\begin{array}{l}\text { Confirmatory Factor } \\
\text { Analysis }\end{array}$ & \multirow[b]{2}{*}{$\begin{array}{l}\text { All four knowledge } \\
\text { conversion factors } \\
\text { or processes } \\
\text { (socialization, } \\
\text { externalization, } \\
\text { combination, and } \\
\text { internalization) } \\
\text { explain a high } \\
\text { variation in the } \\
\text { organizational } \\
\text { knowledge creation } \\
\text { construct. }\end{array}$} \\
\hline $\begin{array}{l}\text { Creation Theory: A } \\
\text { First } \\
\text { Comprehensive } \\
\text { Test }\end{array}$ & & $\begin{array}{l}\text { A business that deals } \\
\text { with a rapidly changing } \\
\text { environment must not } \\
\text { only process information } \\
\text { efficiently but also } \\
\text { produce information and } \\
\text { knowledge. }\end{array}$ & \\
\hline Li et al. (2009) & \multirow{2}{*}{$\begin{array}{l}\text { To examine how } \\
\text { entrepreneurial } \\
\text { orientation } \\
\text { interferes with } \\
\text { business } \\
\text { performance } \\
\text { through the } \\
\text { knowledge creation } \\
\text { process. }\end{array}$} & $\begin{array}{l}\text { Confirmatory Factor } \\
\text { Analysis }\end{array}$ & \multirow[b]{2}{*}{$\begin{array}{l}\text { The results have } \\
\text { shown that } \\
\text { entrepreneurial } \\
\text { orientation can } \\
\text { positively improve } \\
\text { company's } \\
\text { performance. Thus, } \\
\text { the knowledge } \\
\text { creation process } \\
\text { plays a mediating } \\
\text { role by which } \\
\text { entrepreneurial } \\
\text { orientation gives } \\
\text { benefits to } \\
\text { company's } \\
\text { performance. }\end{array}$} \\
\hline $\begin{array}{l}\text { Entrepreneurial } \\
\text { orientation and firm } \\
\text { performance: The } \\
\text { role of knowledge } \\
\text { creation process }\end{array}$ & & $\begin{array}{l}\text { Financial measures, } \\
\text { such as market share } \\
\text { from sales growth, } \\
\text { customer satisfaction, } \\
\text { brand value, etc. are not } \\
\text { enough to measure the } \\
\text { company's performance. }\end{array}$ & \\
\hline $\begin{array}{l}\text { Goonesekera } \\
\text { (2012) }\end{array}$ & $\begin{array}{l}\text { To measure } \\
\text { knowledge } \\
\text { management levels } \\
\text { in organizations in }\end{array}$ & $\begin{array}{l}\text { Fuzzy Logic: } \\
\text { Information System } \\
\text { Success Model (D\&S } \\
\text { Success Model) }\end{array}$ & $\begin{array}{l}\text { The results have } \\
\text { shown that it was } \\
\text { possible to } \\
\text { measure the levels }\end{array}$ \\
\hline
\end{tabular}


Table 1. Continued...

\begin{tabular}{|c|c|c|c|}
\hline $\begin{array}{l}\text { AUTHOR; YEAR } \\
\text { AND WORK }\end{array}$ & AIMS & $\begin{array}{l}\text { METHOD AND } \\
\text { JUSTIFICATION }\end{array}$ & RESULTS \\
\hline $\begin{array}{l}\text { Measuring } \\
\text { knowledge } \\
\text { management } \\
\text { maturity levels in } \\
\text { the manufacturing } \\
\text { sector using the } \\
\text { fuzzy logic theory. }\end{array}$ & $\begin{array}{l}\text { the manufacturing } \\
\text { industry, aiming to } \\
\text { fill this } \\
\text { methodological } \\
\text { gap. }\end{array}$ & $\begin{array}{l}\text { Despite the attention to } \\
\text { the role of knowledge } \\
\text { management, } \\
\text { organizations do not } \\
\text { have criteria defined for } \\
\text { finding out whether or } \\
\text { not they are successful } \\
\text { in knowledge } \\
\text { management. }\end{array}$ & $\begin{array}{l}\text { of knowledge } \\
\text { maturity in each } \\
\text { aspect linked to the } \\
\text { production } \\
\text { department and } \\
\text { thus have more } \\
\text { accuracy for the } \\
\text { investment of } \\
\text { knowledge } \\
\text { management } \\
\text { actions. }\end{array}$ \\
\hline Oskouei (2013) & \multirow{2}{*}{$\begin{array}{l}\text { To investigate and } \\
\text { determine the } \\
\text { knowledge level of } \\
\text { Mashhad } \\
\text { municipality based } \\
\text { on Nonaka \& } \\
\text { Takeuchi model. }\end{array}$} & $\begin{array}{l}\text { Multiple Regression } \\
\text { Analysis }\end{array}$ & \multirow[b]{2}{*}{$\begin{array}{l}\text { It is concluded from } \\
\text { systematization } \\
\text { that the } \\
\text { investments } \\
\text { related to } \\
\text { knowledge are in } \\
\text { medium and low } \\
\text { level, therefore } \\
\text { they were } \\
\text { classified in critical } \\
\text { area. A project } \\
\text { based on } \\
\text { knowledge } \\
\text { management } \\
\text { should be } \\
\text { implemented. }\end{array}$} \\
\hline $\begin{array}{l}\text { Investigation of } \\
\text { Knowledge } \\
\text { Management based } \\
\text { on Nonaka and } \\
\text { Takeuchi Model in } \\
\text { Mashhad } \\
\text { Municipality }\end{array}$ & & $\begin{array}{l}\text { Companies should } \\
\text { make efforts to identify, } \\
\text { capture/acquire, and } \\
\text { share knowledge. The } \\
\text { first step in } \\
\text { implementing } \\
\text { knowledge management } \\
\text { practice is to determine } \\
\text { in what level it is. }\end{array}$ & \\
\hline \multirow[b]{2}{*}{$\begin{array}{l}\text { Akhavan et al. } \\
\text { (2017) Introducing } \\
\text { knowledge } \\
\text { management } \\
\text { pattern at national } \\
\text { level applying } \\
\text { grounded theory } \\
\text { method and fuzzy } \\
\text { dematel }\end{array}$} & \multirow[b]{2}{*}{$\begin{array}{l}\text { To provide a } \\
\text { standard of } \\
\text { implementation of } \\
\text { knowledge } \\
\text { management at the } \\
\text { national level and } \\
\text { also measure the } \\
\text { degree of } \\
\text { correlation and } \\
\text { importance } \\
\text { between the } \\
\text { available concepts. }\end{array}$} & Domatel Fuzzy & \multirow{2}{*}{$\begin{array}{l}\text { A pattern } \\
\text { containing the } \\
\text { main knowledge } \\
\text { management items } \\
\text { has been created. }\end{array}$} \\
\hline & & $\begin{array}{l}\text { It is relevant to create a } \\
\text { guide for implementing } \\
\text { knowledge management } \\
\text { at the national level. }\end{array}$ & \\
\hline
\end{tabular}

Source: own elaboration.

The measurement based on this model, as seen, was tested by Nonaka et al. (1994). Afterwards, several efforts have been undertaken to measure knowledge management. This measurement occurs, broadly speaking, in order to broaden the understanding about the process of knowledge creation and management.

In addition to inspiring the present study, being considered as a reference in knowledge management theory, the Nonaka \& Takeuchi model is also used as the basis for analyzing different study perspectives. The research by Campanella et al. (2019) aimed to verify the existence of any relationship between the knowledge creation process and the competitive advantage in the banking system. To do so, there are specific factors associated with the knowledge spiral, which are relevant to increasing a bank's economic value. In this process of creating value for the banking system, a positive influence has been found. An article by Braga et al. (2017) has shown that the use of the knowledge management model is assertive to describe the 
process of generation, investigation, combination, and internalization of the knowledge at ENEL (Electricity Distribution Company). Moreover, this model was associated with assumptions related to innovation management. A study conducted by Alectoridis et al. (2018) describes the interaction between management accounting and operations' management professionals, from the perspective of the knowledge creation theory developed by Nonaka and Takeuchi. In light of this reasoning, it can be concluded that there are evident difficulties in the process of creating business knowledge in accounting.

Moreover, this model has been widely used for knowledge management assessment in universities. Khodaee's study (2016) investigated the effect of knowledge management on the productivity of professionals working at an Islamic University (Azad University) and found out that the development of knowledge management has an effect on the level of staff productivity. Barari (2015), based on Mazandaran University employees, analyzed the role of knowledge management for organizational innovation and understood that knowledge management has a positive and significant effect on organizational innovation. The authors suggested that the managers of the organization (university) encourage cooperation and entrepreneurship in their interdisciplinary teams. Lastly, the study by Marques et al. (2019) examined the relationship between organizational commitment, knowledge sharing and knowledge management maturity at a higher education university in Brazil. The results showed that organizational commitment influences knowledge sharing and, consequently, has an effect on its level of maturity. Therefore, knowledge management is a driving force for the achievement of organizational goals.

\subsection{Fuzzy Logic and its applicability in knowledge management}

The fuzzy logic allows us to infer degrees of truth from propositions built from linguistic variables. Linguistic variables (words or sentences) can assume values in which degrees of accuracy could not be measured with certainty. Thus, fuzzy logic is capable of shaping human reasoning, which is inaccurate and approximate by nature. Moreover, the application of fuzzy logic can be adapted to various areas of knowledge (Benini, 2012).

With fuzzy logic one can build a "fuzzy set", mathematically defined by assigning a value, which represents the degree of pertinence to the set of each individual in the universe. This degree of pertinence represents the resemblance of this individual to the meaning that gives identity to the whole.

The fuzzy logic and the theory of fuzzy sets are mathematical tools to model uncertain systems in the industry, nature, and humanity. Those sets allow inferences with approximate reasoning in decision making without complete and accurate information. Its performance is important when applied to complex phenomena which are not easily described by traditional mathematical methods, especially when the aim is to find out a better solution (Bojadziev \& Bojadziev, 1995).

Regarding the definition of fuzzy sets, it should be noted that the subsets A of a set $U$ can be considered a fuzzy subset of $U$ if it is described like a set of ordered pairs, as follows: $A=\{(x, \mu A(x)) ; x \varepsilon \cup \mu A(x) \varepsilon[0,1])$ where: $\mu A(x)$ is a membership function that determines how far $x$ is in $A: \mu_{A}(x)=1 x$ belongs entirely to the set $A ; 0<\mu_{A}(x)$ $<x$ belongs partially to the set $A ; \mu_{A}(x)=0 x$ does not belong to set $A$. A fuzzy number is a convex and normalized fuzzy set. 
Based on the binary logic of polarized truth (related to absolute truths and falsehoods), in the classical set theory, there are situations in which the relation of relevance is not well defined and, in those cases, it is not possible to classify the elements analyzed as belonging or not to a given set. Zadeh (1965) has made adjustments to the belonging of elements in the set and created the degrees of pertinence. The degrees of relevance (or function of relevance) can be represented by: $\mu():. X \rightarrow[0,1]$ (Tan \& Cruz, 2004).

Thus, fuzzy logic allows partial belonging to the analyzed sets. For instance, a member may belong to $80 \%$ in set A while $20 \%$ in set B. Fuzzy sets incorporate from extreme belonging values $[0,1]$ to gradual values, from 0 to 1 . Therefore, the applied method of fuzzy sets differs from Boolean mathematics as it allows the same object to belong simultaneously to two sets with different degrees of belonging to each other.

An application: how to precisely define and classify a company's knowledge management maturity by combining the dimensions (socialization, externalization, blending, and internalization) of knowledge that define maturity for companies. The term "degree of maturity" is a linguistic value assumed by the linguistic variable "maturity," with inherent degrees of inaccuracy and vagueness, since it is difficult to define it precisely. There may not be a single Knowledge Management Maturity level for these dimensions, but it may be identified at the following levels: low, medium-low, medium, medium-high, and high. Besides, the result may fit into more than one maturity level. It can also have a maturity of $90 \%$ in medium grade and $10 \%$ in medium-high, for example. This measure demonstrates the gradual effect of belonging. In this case, there is no abrupt break up in a set, by not following the "yes/no" or "true/false" logic. Based on the validation of the mentioned maturity, it will be possible to define the level of knowledge management of companies.

\subsection{Fuzzy inference system construction}

In the process of measuring organizational knowledge, fuzzy inference of the Mamdani type will be applied using MATLAB software (Version 2017a, license 40588780). Mamdani fuzzy inference systems are used to model complex, nonlinear and vague processes. From this perspective, measuring knowledge management maturity can be qualified as a nonlinear way to study subjectivity, as it seeks quantifying a knowledge and learning process that may be inaccurate or ambiguous.

Each step related to the construction of the fuzzy system was outlined in order to describe the steps for building the main analysis (knowledge management maturity) and complementary analysis (management level). Table 1 shows the dimensions and indicators of fuzzy organizational knowledge management system. All the values responded for each variable related to the knowledge management dimensions were classified as initial, intermediate and advanced. The congeries of these variables will result in knowledge management maturity. Therefore, each dimension of knowledge management has had five variables and the measurement of these variables has defined the maturity of knowledge management obtained at the main level of analysis.

The complementary perspective, knowledge management level, included the aggregation of the 4 dimensions of knowledge (socialization, externalization, combination, and internalization) and their respective maturity (low, medium-low, medium, medium-high, and high). The possible combination of maturity between dimensions classifies the level of knowledge management (unsatisfactory, median, and 
satisfactory). It should be emphasized that the output variables of the main analysis are the input variables of the secondary analysis, which can be seen in Chart 1 the below.

Fuzzy inference systems consist of the following steps, namely: i) fuzzification (input), ii) fuzzy inferencing (rule evaluation) and iii) defuzzification (outputs), illustrated below (Figure 2).

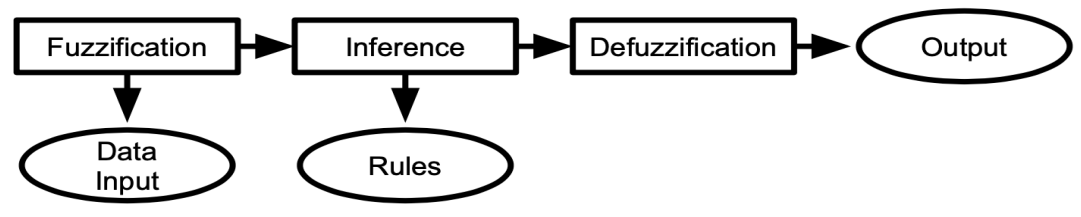

Figure 2. Example of a typical fuzzy model. Source: Goonesekera (2012). Adapted by the authors.

In fuzzification, it is possible to model the input variables of fuzzy sets mathematically by assigning relative values to each variable. At this stage, it is fundamental to have an expert knowledge in the parameter process, since each input variable has linguistic terms that represent the level/state of the variable. Each linguistic term will be associated with fuzzy sets by a function pertinency (Amendola et al., 2005).

The second step of the process is called inference and represents the junction between input (linguistic) variables and output variables. The central objective of this phase is to relate the possible variables and establish an association based on preestablished rules. In this phase there are two components: aggregation and composition. Aggregation is an "If" condition and defines the validation of inference rules. The composition is guided by the "Then" and establishes the results. The link between the two components conforms to the If-Then rule set (Jané, 2004). In this step it is possible to "save" the variables and their linguistic classifications (Amendola et al., 2005).

The second step in the process is called inference, and it represents the junction between input (linguistic) variables and output variables. The central objective of this phase is to relate the possible variables and establish an association from the rules previously established. In this phase, the two components are triggered: aggregation (“If”) and composition (“Then") (Jané, 2004; Amendola et al., 2005).

The set of rules is capable of composing an inference system in its range of possibilities, as the antecedents condition the premises for the function. The consequents explain the implications of the premises (Ortega, 2001). Following, there is an example of a rule configuration based on the classic example (body temperature). If an individual has low body temperature then he is not sick. IF an individual has an average body temperature THEN he's a little sick. IF an individual has high body temperature THEN he is very ill.

The construction of the rules is made based on the truth tables of logic, which allows the researcher to combine all possible options of the antecedent "If " to generate a possible answer to the consequent "Then". The number of rules is established through a mathematical power, which considers the number of variables in the analysis and the number of linguistic terms established to each input variable. 
Chart 1. Dimensions, indicators and configuration of the fuzzy organizational knowledge management system.

Main Analysis: Comparative Analysis of Knowledge Management Maturity in Each Dimension - Segmented by Size

Variables: Initial, Intermediate, and Advanced / Maturity: Low, Medium-Low, Medium, Medium-High, and High

\begin{tabular}{|c|c|c|}
\hline $\begin{array}{l}\text { Analyzed Dimensions and } \\
\text { Variables }\end{array}$ & $\begin{array}{l}\text { Fuzzy Set Limits } \\
\text { Variable Analysis }\end{array}$ & $\begin{array}{l}\text { Fuzzy Suite Limits } \\
\text { Management Maturity } \\
\text { Analysis }\end{array}$ \\
\hline $\begin{array}{l}\text { Socialization: Formal training, } \\
\text { informal activities, relationship } \\
\text { with external project team, } \\
\text { product and/or service quality } \\
\text { and revenue growth }\end{array}$ & $\begin{array}{l}\text { Initial: Less than } 0.5 \\
\text { Intermediate: } \\
\text { Between } 0,25 \text {, and } \\
0.75 \text { Advanced: } \\
\text { Greater than } 0.5\end{array}$ & $\begin{array}{l}\text { Low: Below } 0.5 \text { / Medium-Low: } \\
\text { Between } 0 \text { and } 0.5 \text { / Medium: } \\
\text { Between } 0.25 \text { and } 0.75 \text { / } \\
\text { Medium-High: Between } 0.5 \text { and } \\
0.75 \text { / High: Above } 0.75\end{array}$ \\
\hline $\begin{array}{l}\text { Outsourcing: Collaborative } \\
\text { work, formal practices, } \\
\text { knowledge sharing, } \\
\text { introduction of new products } \\
\text { and/or services and synergy } \\
\text { between units. }\end{array}$ & $\begin{array}{l}\text { Conditioned Limits } \\
\text { on the Program. }\end{array}$ & $\begin{array}{l}\text { Conditioned Limits on the } \\
\text { Program }\end{array}$ \\
\hline $\begin{array}{l}\text { Combination: database } \\
\text { existence, network access, } \\
\text { incentive, partnerships, and } \\
\text { marketing investment }\end{array}$ & $\begin{array}{l}\text { Initial: }\left[\begin{array}{llll}0 & 0 & 0.25 & 0.5\end{array}\right] \\
\text { Intermediate: }\left[\begin{array}{ll}0.25 \\
0.5 & 0.75\end{array}\right] \text { Advanced: } \\
{\left[\begin{array}{llll}0.5 & 0.75 & 1 & 1\end{array}\right]}\end{array}$ & $\begin{array}{l}\text { Low: }[0,0,0.25] \text { Medium-low }[0, \\
0.25,0.5] \text { Medium: }[0.25,0.5, \\
0.75] \text { Medium-high: }[0.5,0.75 \text {, } \\
\text { 1] High: }[0.75,1,1] .\end{array}$ \\
\hline $\begin{array}{l}\text { Internalization: Capacity } \\
\text { Building, Sharing Culture, } \\
\text { Written Documentation } \\
\text { Storage, Enhanced Skills, and } \\
\text { Organizational Culture }\end{array}$ & & \\
\hline \multicolumn{3}{|c|}{$\begin{array}{l}\text { Complementary Analysis: Comparative analysis of possible combinations between } \\
\text { maturities in knowledge dimensions to shape the level of knowledge management }\end{array}$} \\
\hline \multicolumn{3}{|c|}{ Levels: Unsatisfactory, Median and Satisfactory } \\
\hline \multirow{4}{*}{$\begin{array}{l}\text { Management Level: SECI } \\
\text { Dimensions (Socialization, } \\
\text { Externalization, Combination } \\
\text { and Internalization) }\end{array}$} & \multicolumn{2}{|c|}{ Fuzzy Suite Limits Management Level Analysis } \\
\hline & \multicolumn{2}{|c|}{$\begin{array}{l}\text { Initial: Less than } 0.5 \text { Intermediate: Between } 0.25 \text { and } \\
0.75 \text { Advanced: Higher than } 0.5\end{array}$} \\
\hline & \multicolumn{2}{|c|}{ Conditioned Limits on the Program } \\
\hline & \multicolumn{2}{|c|}{$\begin{array}{l}\text { Unsatisfactory: }\left[\begin{array}{llll}0 & 0 & 0.25 & 0.5\end{array}\right] \text { Median: }\left[\begin{array}{llll}0.25 & 0.5 & 0.75\end{array}\right] \\
\text { Satisfactory: }\left[\begin{array}{llll}0.5 & 0.75 & 1 & 1\end{array}\right]\end{array}$} \\
\hline
\end{tabular}

Source: own elaboration.

For the calculation related to each of the management maturity dimensions, the number of rules is defined by $\left(3^{5}\right)$, as 3 represents the linguistic terms of each variable (initial, intermediate, advanced) and (5) the number of linguistic input variables for each dimension. In this case, the number of rules was 243 for each dimension. It is noteworthy that the rules adopted are equivalent for all dimensions. One of the extreme situations of the rules is as follows: IF "outside environment training" is initial AND IF "sharing culture" is initial AND IF "written documentation" is initial AND IF "enhanced skills" is initial AND IF "dissemination of organizational culture" is initial, THEN "knowledge management maturity" is low.

Following the same logic to define the number of rules, the management level contained 625 rules, based on $\left(5^{4}\right)$, as 5 represents the language terms related to knowledge management maturity (low, medium-low, medium, medium-high and high) 
and 4 the number of input variables, which corresponds to the number of dimensions of knowledge management (socialization, externalization, combination, and internalization). One of the extreme situations of the rules is as follows: IF socialization is high AND IF externalization is high AND IF combination is high AND IF internalization is high, THEN knowledge management level is satisfactory. Additionally, one of the positive aspects of fuzzy is that the establishment of rules and concepts depends on analysts' knowledge, allowing greater freedom of configuration and analysis.

The last step is called defuzzification, in which the "translation" of qualitative (or linguistic) output results is obtained into a numerical value (Jané, 2004). It is a procedure to interpret the distribution of output possibilities of a fuzzy linguistic model quantitatively, in other words, it is a numerical value provided which represents the capture of the essential meaning of the distribution of possibilities (Ortega, 2001). In this study, the defuzzification has been done by the Area Center (COA), and the output value is represented by its center of gravity of the possibility distribution function (Sandri \& Correa, 1999).

An inference system was created for each dimension. Each dimension was analyzed according to its variables and the relationship established between them. It is worth remembering that the inputs of this fuzzy system are the fuzzy outputs of each dimension previously analyzed. That is, the outputs of the dimensions "Socialization", "Externalization", "Combination", and "Internalization" are the inputs of the inference system related to the composition of inference system called the "knowledge management level" (Amendola et al., 2005).

Finally, the inference system is capable of presenting the logical connectors built to establish the relationship of the fuzzy system that models the rules base. At this phase, the success of the fuzzy system is established, once the fuzzy output (control) is available to be adopted by the controller from each fuzzy input (Amendola et al., 2005). The main level of analysis (from the example of "internalization") and the secondary analysis corresponding to the level of knowledge management analysis can be seen in Figure 3.
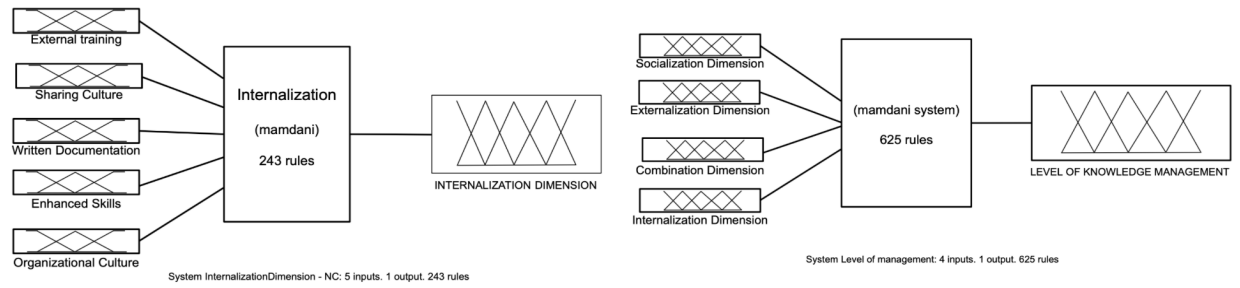

Figure 3. Fuzzy Inference System: "Internalization" and "Management Level". Source: own elaboration.

The results of these values are presented in the next session. These steps can be visualized through the flowchart related to Figure 4.

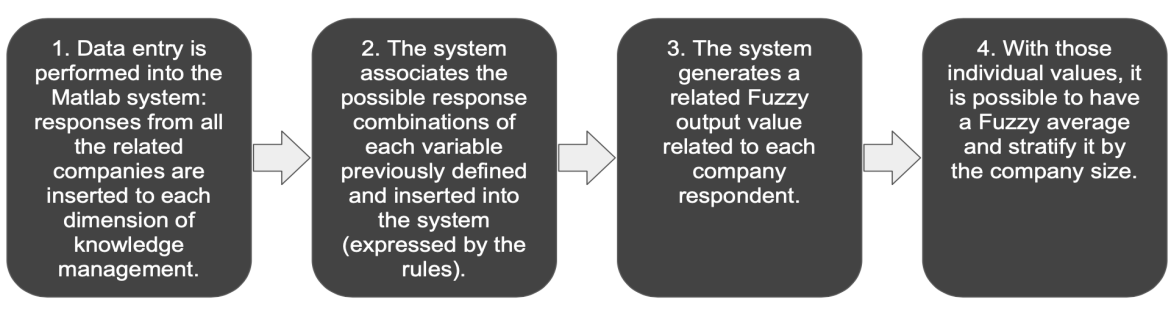

Figure 4. Flowchart steps for Fuzzy averaging. Source: own elaboration. 
The association functions are determined after the Fuzzy language variables are identified. The Fuzzy Membership Function (MF) is a mathematical function used to map input (linguistic) with an associated number value (or degree of association) between 0 and 1 . Thus, the triangular and the trapezoidal association functions were used in this study.

\section{Methodological procedures}

A primary data collection was performed with a qualitative and quantitative approach, which uses Fuzzy Logic as a way of relation of propositions, which allowed to parameterize, mathematically (quantitative element), the linguistic variables that represent subjective aspects, related to the perception of respondents (qualitative dimension). The details of the research steps can be seen on Figure 5. And the research design can be seen on Figures 6 and 7 .

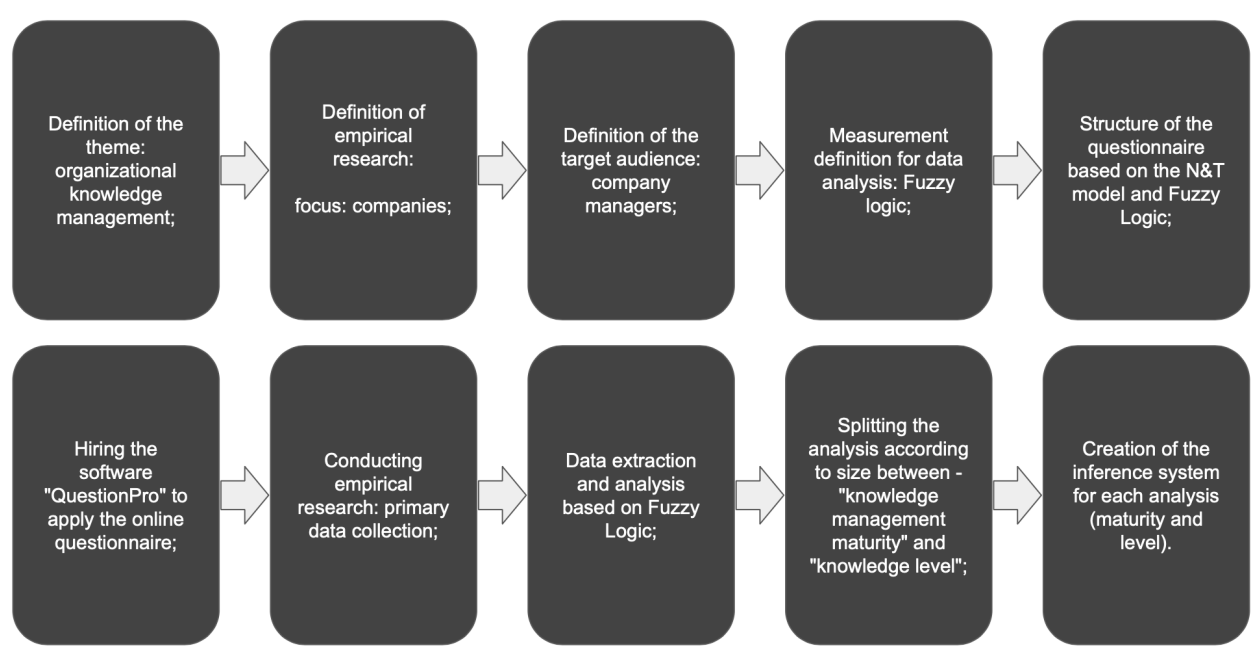

Figure 5. Flowchart of research steps. Source: own elaboration.

The analysis base was collected through a structured questionnaire answered by managers of 108 companies located in the following states: São Paulo, Minas Gerais, and Rio de Janeiro. The operating sectors of the industrial companies studied were heterogeneous. Data collection began in May/2018 and ended in July/2018. A pilot survey was conducted with 15 respondents to find out if the questions applied in the questionnaire were consistent. After the testing and validation phase, the questionnaire was applied.

The sample data were classified into three groups of companies, considering the number of employees: i) small-sized (20 to 99 employees); ii) medium-sized (100 to 499 employees) and iii) large-sized (above 499). This classification was based on the methodology of SEBRAE (Brazilian Micro and Small Business Support Service) (SEBRAE, 2018).

It is believed that "traditional" questionnaires tend to impose a simplistic interpretation of data. However, in a complex reality it is difficult to describe "a priori" determination that may make it impossible to obtain responses within a broader range of possibilities, which may lead the research to the reduction of the respondent's freedom of expression and the inaccurate capture of their perceptions (Guerrero et al., 2000). 


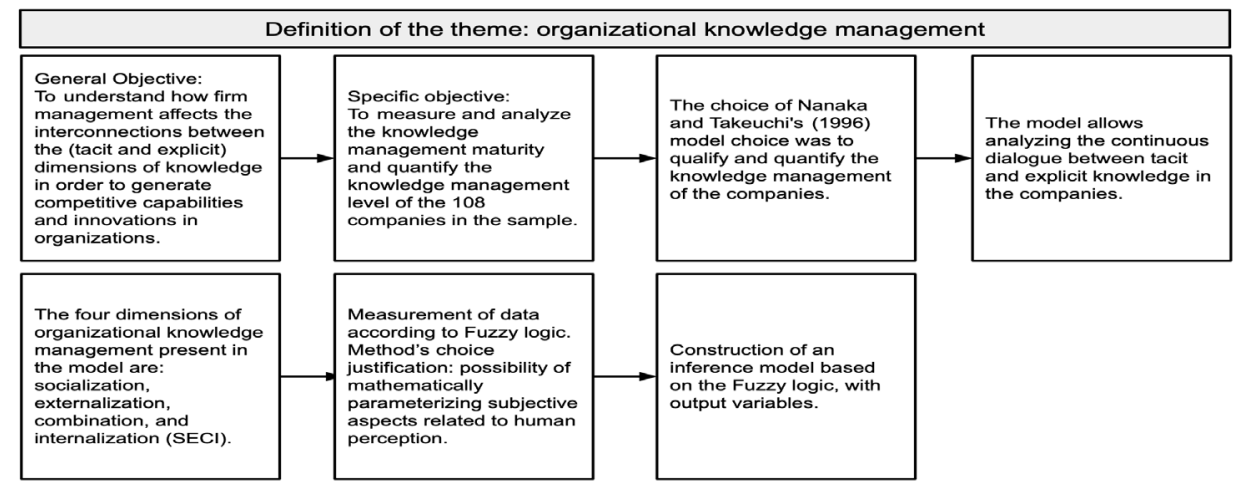

Figure 6. Research Design - Theme Definition. Source: own elaboration.

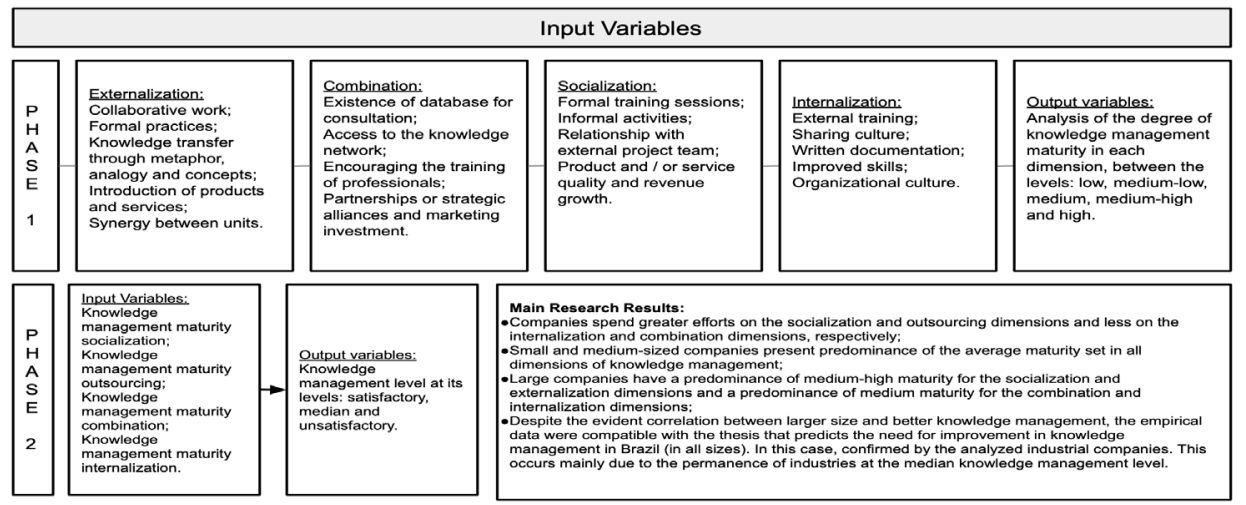

Figure 7. Survey Design - Survey Steps. Source: own elaboration.

The difference between the Likert scale and the ruler-style response capture format is that, on the Likert scale, the participant in the survey must give an answer corresponding to an integer. In addition, the Likert scale provides ordering, without measuring the distance between each option. In the ruler, the respondent can express his choice more freely, without choosing a number, but rather a position in the ruler that expresses higher or lower levels of what is asked, even expressing a notion of distance between situations, as it will be shown in Figure 8.

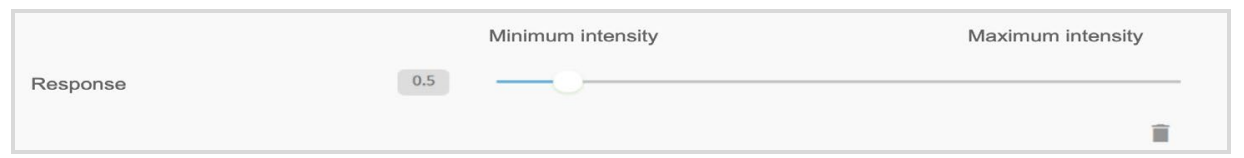

Figure 8. Answer to question ascertained by ruler form. Source: QuestionPro website.

The questionnaire consisted of thirty-one questions. The first five questions asked about general aspects of the company, such as: (size, sector, and location of the industry), and the last question was an open-ended question (descriptive), in which the respondents could briefly describe their perception on knowledge management in the company they work. The second part of the questionnaire consisted of twenty-six questions and was related to knowledge management itself. To each dimension of knowledge (socialization, externalization, combination, and internalization), there were five specific questions. 


\section{Analysis and discussion of results}

Knowledge management maturity was analyzed in each dimension (socialization, externalization, combination and internalization) segmented by size. Subsequently, the analysis ends with the definition of organizational knowledge management levels (unsatisfactory, satisfactory, and median), calculated from the combination of the maturities observed in each dimension of knowledge management.

From the data collected and stored by the QuestionPro software, 108 answers were validated. Data collection effectively began in May/2018 and ended in July/2018. The sample consisted of 108 industrial companies from the states of São Paulo, Minas Gerais, and Rio de Janeiro. From those, $18 \%$ belong to a large-sized company group; $39 \%$ are medium-sized, and $43 \%$ small-sized. Regarding the positions of respondents, $80 \%$ are managers and $20 \%$ occupy management positions.

After data collection, the MATLAB software was used to stipulate the maturity and level of organizational knowledge management. It was possible to assign a specific fuzzy number to each company, representing the manager's perception. From this number it was possible to apply the average fuzzy numbers. The concept of averaging can be applied to fuzzy numbers by dividing them by a real number. Thus, it is possible to perform arithmetic operations with fuzzy numbers. When considering $n$ fuzzy numbers, one must use the addition of these numbers and divide them by a real number, based on the fuzzy average (Bojadziev, 2007).

Table 2 summarizes the analysis of the fuzzy average and shows the relationship of fuzzy values according to the degrees of relevance to each set analyzed, as well as any logic that may occur to more than one set. For sample stratification and data analysis, the different sizes of the companies (small, medium, and large) were considered, as shown in the methodology. The dimensions will be represented by their initial letters, namely: i) S (Socialization); ii) E (Externalization); iii) C (Combination); and iv) I (Internalization). The data are based on the answers about knowledge management given by the participants.

Table 2. Results stratified by size based on the average fuzzy numbers of each company.

\begin{tabular}{|c|c|c|c|c|c|c|c|c|}
\hline Size/Dimension & $\mathbf{s}$ & $\begin{array}{l}\text { Linguistic } \\
\text { Variable }\end{array}$ & $E$ & $\begin{array}{c}\text { Linguistic } \\
\text { Variable }\end{array}$ & C & $\begin{array}{c}\text { Linguistic } \\
\text { Variable }\end{array}$ & I & $\begin{array}{c}\text { Linguistic } \\
\text { Variable }\end{array}$ \\
\hline Small-sized & 0.58 & $\begin{array}{l}75 \% \\
\text { Medium } \\
\text { and } 25 \% \\
\text { Medium- } \\
\text { High }\end{array}$ & 0.56 & $\begin{array}{c}77 \% \\
\text { Medium } \\
\text { and } 23 \% \\
\text { Medium- } \\
\text { High }\end{array}$ & 0.45 & $\begin{array}{l}79 \% \\
\text { Medium } \\
\text { and } 21 \% \\
\text { Medium- } \\
\text { Low }\end{array}$ & 0.42 & $\begin{array}{c}70 \% \\
\text { Medium } \\
\text { and } 30 \% \\
\text { Medium- } \\
\text { Low }\end{array}$ \\
\hline Medium-sized & 0.6 & $\begin{array}{c}60 \% \\
\text { Medium } \\
\text { and } 40 \% \\
\text { Medium- } \\
\text { High }\end{array}$ & 0.58 & $\begin{array}{l}75 \% \\
\text { Medium } \\
\text { and } 25 \% \\
\text { Medium- } \\
\text { High }\end{array}$ & 0.5 & $\begin{array}{c}100 \% \\
\text { Medium }\end{array}$ & 0.46 & $\begin{array}{c}80 \% \\
\text { Medium } \\
\text { and } 20 \% \\
\text { Medium- } \\
\text { Low }\end{array}$ \\
\hline Large-sized & 0.7 & $\begin{array}{c}80 \% \\
\text { Medium- } \\
\text { High and } \\
20 \% \\
\text { Medium }\end{array}$ & 0.68 & $\begin{array}{l}78 \% \\
\text { Medium- } \\
\text { High and } \\
22 \% \\
\text { Medium }\end{array}$ & 0.6 & $\begin{array}{l}60 \% \\
\text { Medium } \\
\text { and } 40 \% \\
\text { Medium- } \\
\text { High }\end{array}$ & 0.59 & $\begin{array}{c}63 \% \\
\text { Medium } \\
\text { and } 37 \% \\
\text { Medium- } \\
\text { High }\end{array}$ \\
\hline
\end{tabular}

Source: own elaboration. 
The results are presented by knowledge management maturity in each dimension according to the size of the company analyzed. The socialization dimension (interaction of tacit knowledge to tacit) relates to the following items: i) if the organization provides formal training internally, covering technical and behavioral content; ii) if informal activities are promoted related to the encouragement of exposing ideas (brainstorming, conversation circles, etc.); iii) if its professionals are encouraged to participate in project teams with external experts in order to share technical skills; iv) the pursuit of knowledge management aimed at improving products, services and processes; and v) if it invests in improving the quality of products and/or services and raising revenues.

In the small-sized business group, knowledge management maturity is between Medium (75\%) and Medium-High (25\%). On the other hand, the medium-sized companies have concentrated the answers that correspond to the maturity Medium $(60 \%)$ and Medium-High (40\%). Finally, in the large-sized companies, sets associated with the levels of maturity Medium-High (80\%) and Medium (20\%) predominate. Figure 9 shows the pertinence in the sets.

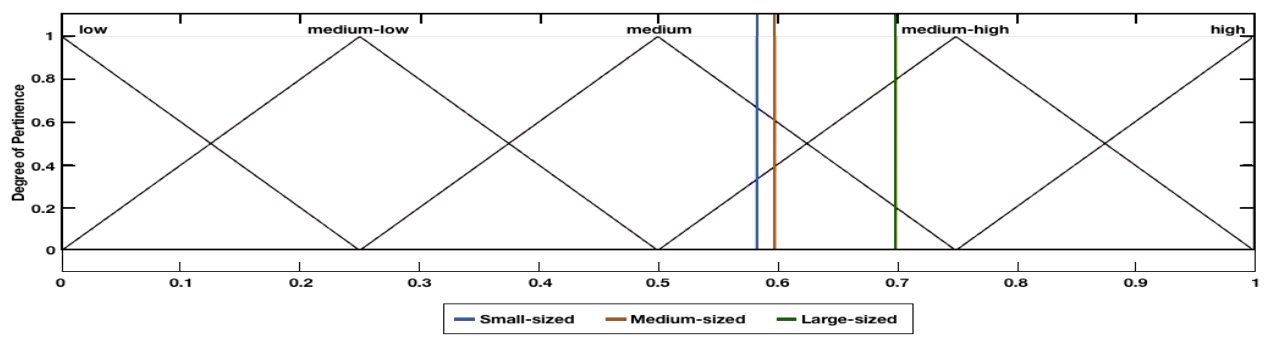

Figure 9. Demonstration of fuzzy average by company size - Socialization dimension. Source: own elaboration.

The externalization dimension (interaction of tacit to explicit knowledge) assesses if the company: i) promotes actions aiming to facilitate collaborative work in teams that are physically separated; ii) uses formal practices (construction of hypothetical models and simulation of real situations) for the development of the work; iii) has practices that encourage experienced workers to share their knowledge to new or less experienced professionals; iv) has introduced new products or services in the last 3 years; and ( $v$ ) if synergies have been created between industry units or departments within or outside the same physical environment. The knowledge management maturity calculated to the externalization dimension has shown that, in small-sized companies, maturity is at the levels: Medium (77\%) and Medium-High (23\%). For medium-sized companies, maturity is between Medium (75\%) and Medium-High (25\%). In large-sized companies, the levels found were Medium-High (78\%) and Medium (22\%), as shown in Figure 10.

The combination dimension (interaction of explicit knowledge to explicit) relates to the following items, namely, if: i) there is knowledge sharing from a database with regular updates, better working practices, lessons learned, and expert advice (for consultation) in the company; ii) there is access to the computer network in which specific knowledge is stored, related to the work to be performed; (iii) the company encourages its professionals to continue their training by offering tuition fees for workrelated courses, or by partnering with universities that offer them discounts; iv) partnerships or strategic alliances are established to acquire knowledge (with other 
companies/universities/discussion centers, etc.); and v) the company invests in marketing actions to create new sales systems and methods.

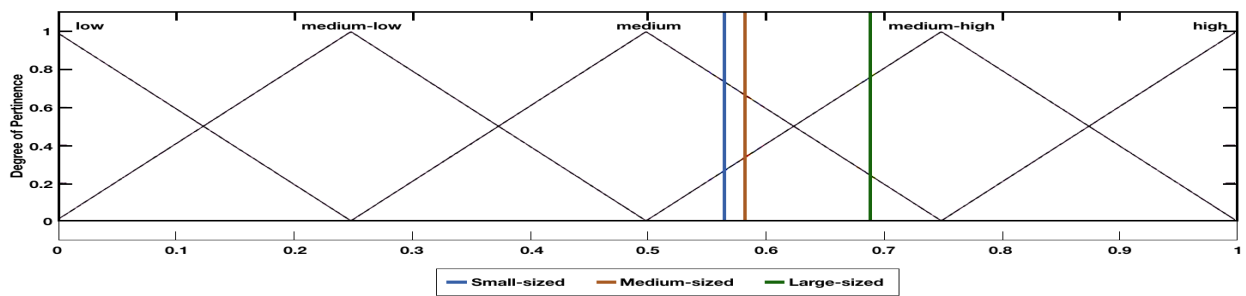

Figure 10. Demonstration of fuzzy average by size - Externalization dimension. Source: own elaboration.

Regarding the dimension Combination, the maturity in small companies is between Medium (79\%) and Medium-Low (21\%); Medium-sized companies it is Medium $(100 \%)$, Large-Medium companies it is between Medium $(60 \%)$ and Medium-High $(40 \%)$. The degree of relevance to the sets can be seen in Figure 11.

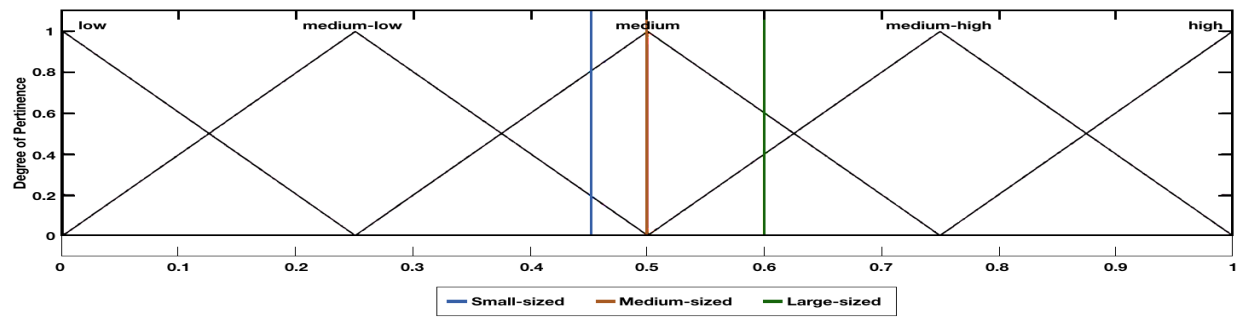

Figure 11. Demonstration of fuzzy average by company size - Combination dimension. Source: own elaboration.

The internalization dimension (interaction between explicit and tacit knowledge) analyzes if the company: i) provides training (e.g.: fair knowledge, workshops, etc.) outside the workplace to their workers ; ii) has a value system or culture that promotes knowledge sharing; iii) resources are expended to develop means of storing written documentation, such as specific manuals of work to be performed; iv) enhances and values the skills aimed at broadening the knowledge of professionals (interaction and sharing of mental models and know-how); v) spreads the organizational culture. For this dimension, small companies marked their management in the Medium (70\%) and Low-Medium (30\%) categories. In medium-sized organizations, this aspect was quantified between Medium (80\%) and Low-Medium (20\%). In large institutions, however, their level was between Medium (63\%) and Medium-High (37\%), as shown in Figure 12.

In general, for the four dimensions analyzed (Socialization, Externalization, Combination, and Internalization), companies apply greater efforts on the Socialization and Externalization dimensions and lesser on the Internalization and Combination dimensions, respectively. Small and medium-sized companies present predominance of the Medium maturity set to all dimensions of knowledge management. Large-sized companies, on the other hand, have a predominance of Medium-High maturity for the Socialization and Externalization dimensions and the predominance of Medium maturity in shifting to High maturity. 


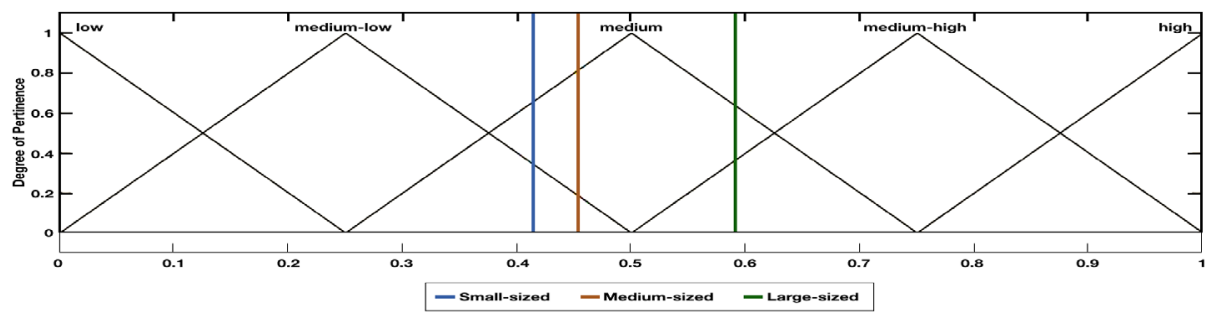

Figure 12. Demonstration of fuzzy average by size - Internalization dimension. Source: own elaboration.

In order to complement the analysis of this maturity, the knowledge management level was calculated based on the average of the fuzzy numbers of each industry in the sample.

Table 3. Level Results of Knowledge Management.

\begin{tabular}{ccc}
\hline Company size & Knowledge Management Level & Linguistic Variable \\
\hline Small & 0.50 & $100 \%$ Median \\
\hline Medium & 0.54 & $96 \%$ Median and $4 \%$ Satisfactory \\
\hline Large & 0.60 & $60 \%$ Median and $40 \%$ Satisfactory \\
\hline
\end{tabular}

Source: own elaboration.

Conform shows Table 3 the level of knowledge management in the companies' sample (of all sizes) are predominantly at the "Median" level. However, there are some differences. In small firms, there is a full relevance at the Median level. In medium-sized companies, there is a small percentage at a satisfactory level. In large companies, however, compared to small and medium-sized companies, there is a significant percentage at a satisfactory level, corresponding to approximately $40 \%$. The result of the knowledge management level can be seen in Figure 13.

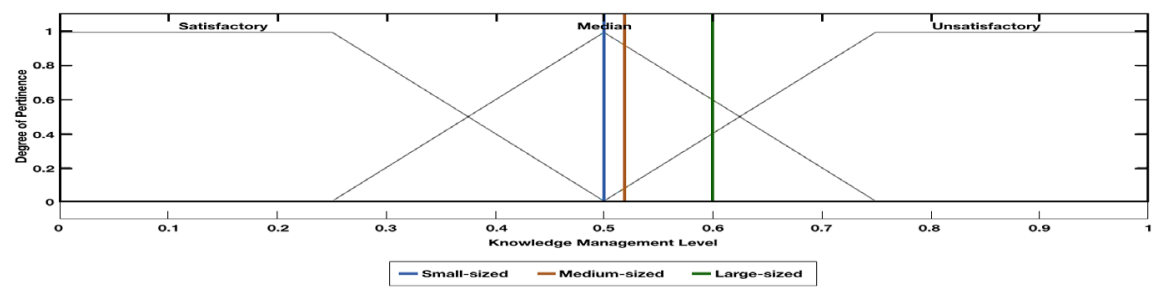

Figure 13. Fuzzy Average Demo by Size - Knowledge Management Level. Source: own elaboration.

However, even with the considerable positive correlation between knowledge level and size, there is a need for improvements in this type of management in all of them.

\section{Conclusion}

Knowledge is an intangible asset and a fundamental source of competitive advantage for companies, notably in the generation and maintenance of innovations. Proper knowledge management involves the definition, systematization, and 
measurement of organizational knowledge, essential factors for the formulation of strategies, and the company's nuclear competitiveness, by broadening the absorption of external knowledge, improving communication, quality of services, increasing sales, better project management that impact company performance.

In this study the Nonaka and Takeuchi (N\&T) model of organizational knowledge management was applied to a sample of companies (segmented by size) from the states of São Paulo, Minas Gerais and Rio de Janeiro, using the logic of fuzzy sets. Seeking to assess their knowledge management maturity and their ability to exercise their skills of knowledge management internally.

The evaluation metric was composed of inferential systems with their respective input and output variables, which constitute a model capable of providing the basis for the aimed objectives. The results have shown that, although large companies have higher maturity and knowledge management level, the related processes remain at median levels, which shows that there are opportunities for potential improvements. The research results listed the possibilities for advances and suggested interventions to the dimensions of knowledge management. Values have been established for these dimensions, defining maturity as low, medium-low, medium, medium-high, or high. These values do not simply represent the average of the values indicated by managers in their answers, they also make up the result of the inference of the rules defined for the sets in fuzzy logic, which enables the measurement of uncertainties of the complex environment that involves organizational knowledge.

Regarding the degree of maturity of knowledge management, the results show that companies spend greater efforts on variables connected to the socialization and externalization dimensions and lesser efforts on internalization and combination. Moreover, the medium maturity in small and medium-sized companies predominates and the medium-high maturity among large companies predominates for the socialization and externalization dimensions and medium for the combination and internalization dimensions. It is remarkable that even among large companies, the percentage of those with a high degree of knowledge management maturity is low.

In addition, the most significant aspects related to knowledge management in large industries were associated with the shortage of professional incentives for academic activities, as well as the absence of partnerships and strategic alliances with other companies or universities, and low investment in marketing actions. Concerning strengths, it stands out the search for knowledge management aiming at product improving, services, and processes. There is a concern about transferring knowledge to improve the quality of products or services, as well as taking actions that involve knowledge to raise revenues.

In the sample as a whole, the median level of knowledge management predominates. However, there are some differences to be highlighted. In small firms, there is a full preponderance at the median level. In medium-sized companies there is a small percentage in the satisfactory level. In large-sized companies, compared to small and medium companies, there is a higher percentage in the satisfactory level, corresponding to $40 \%$. Nevertheless, there was a positive correlation between the level of knowledge management and the size of the companies.

However, there is a need for improvements of management for all sizes. An organizational maturity assessment serves as a guide for the continuous improvement of companies. There may be some bias regarding the respondent (manager of the surveyed company), as the options marked in the questionnaire reflect its perception of the company's knowledge management. The empirical data have shown 
compatibility with the thesis that points out the need for improvement of knowledge management in industries located in Brazil. Finally, regarding management implications, it is recommended that companies measure their professionals' perceptions of their levels of knowledge management in order to identify which elements require more attention or investment. Companies need to potentialize efforts to provide their staff with the continuous development of competencies, promotion, and sharing of knowledge, which must be embedded in the organizational culture to boost their performance.

\section{References}

Akhavan, P., Nabizadeh, M., \& Rajabion, L. (2017). Introducing knowledge management pattern at national level applying grounded theory method and fuzzy dematel. VINE Journal of Information and Knowledge Management Systems, 47(3), 372-394. http://dx.doi.org/10.1108/VJIKMS-05-2016-0022.

Alectoridis, D., Oyadomari, J. C. T., Carneiro, W. N., \& Antunes, M. T. P. (2018). Criação e socialização do conhecimento: estudo com profissionais de controladoria e operações. Revista Contemporânea de Contabilidade, 15(35), 179-203. http://dx.doi.org/10.5007/21758069.2018v15n35p179.

Amendola, M., Souza, A. D., Barros, L. C. (2005). Manual do uso da teoria dos conjuntos Fuzzy no MATLAB 6.5 (pp. 1-44). FEAGRI \& IMECC/UNICAMP.

BARARI, R. (2015). The effect role of knowledge management on organizational innovation in University of Iran. International Journal of Educational and Psychological Researches. 1(2), 87-95.

Benini, L. (2012). Uma introdução à teoria dos conjuntos fuzzy. Natal: Editora UFRN.

Bojadziev, G. (2007). Fuzzy logic for business, finance, and management (Vol. 23). Singapore: World Scientific. http://dx.doi.org/10.1142/6451.

Bojadziev, G., \& Bojadziev, M. (1995). Fuzzy sets, fuzzy logics, applications. Singapore: World Scientific. http://dx.doi.org/10.1142/2867.

Braga, D. S. G., de Menezes, B. S., Silva, J. C. L., Fo., \& Aguiar, Í. C. (2017). Gestão da inovação: um estudo com uma empresa distribuidora de energia elétrica. Gestao e Desenvolvimento, 14(1), 18-33.

Ancori, B., Bureth, A., \& Cohendet, P. (2000). The economics of knowledge: the debate about codification and tacit knowledge. Industrial and Corporate Change, 9(2), 255-287. http://dx.doi.org/10.1093/icc/9.2.255.

Campanella, F., Derhy, A., \& Gangi, F. (2019). Knowledge management and value creation in the post-crisis banking system. Journal of Knowledge Management, 23(2), 263-278. http://dx.doi.org/10.1108/JKM-11-2017-0506.

Cowan, R., David, P. A., \& Foray, D. (2000). The explicit economics of knowledge codification and tacitness. Industrial and Corporate Change, 9(2), 211-253. http://dx.doi.org/10.1093/icc/9.2.211.

Darroch, J. (2003). Developing a measure of knowledge management behaviors and practices. Journal of Knowledge Management, 7(5), 41-54. http://dx.doi.org/10.1108/13673270310505377.

Davenport, T. H., \& Prusak, L. (1998). Conhecimento empresarial: como as empresas gerenciam seu capital intelectual. Rio de Janeiro: Campus.

Foray, D. (2007). Tacit and codified knowledge. In H. Hanusch \& A. Pyka (Eds.), Elgar companion to neo-schumpeterian economics (Chap. 15). Cheltenham, UK: Edward Elgar Publishing. http://dx.doi.org/10.4337/9781847207012.00023. 
Goonesekera, T. (2012). Measuring knowledge management maturity levels in the manufacturing sector using fuzzy logic theory (Doctoral dissertation). La Trobe University, Australia.

Guerrero, L., Lazzari, L., \& Machado, E. (2000). Hacia un cambio de paradigma en la investigación de mercado. Cuadernos del CIMBAGE, (2), 107-129.

Jané, D. D. A. (2004). Uma introdução ao estudo da lógica fuzzy. Hórus, 2, 1-16.

Leonardi, J., \& Bastos, R. C. (2014). Bases epistemológicas da teoria de criação de conhecimento organizacional. Perspectivas em Gestão \& Conhecimento, 4(2), 3-18.

Li, Y. H., Huang, J. W., \& Tsai, M. T. (2009). Entrepreneurial orientation and firm performance: the role of knowledge creation process. Industrial Marketing Management, 38(4), 440-449. http://dx.doi.org/10.1016/j.indmarman.2008.02.004.

Lin, H. F. (2007). A stage model of knowledge management: an empirical investigation of process and effectiveness. Journal of Information Science, 33(6), 643-659. http://dx.doi.org/10.1177/0165551506076395.

Marques, J. M. R., La Falce, J. L., Marques, F. M. F. R., De Muylder, C. F., \& Silva, J. T. M. (2019). The relationship between organizational commitment, knowledge transfer and knowledge management maturity. Journal of Knowledge Management, 23(3), 489-507. http://dx.doi.org/10.1108/JKM-03-2018-0199.

Nelson, R., \& Winter, S. (1982). An evolutionary theory of economic change. Cambridge: Harvard University Press.

Nonaka, I. (1994). A dynamic theory of organizational knowledge creation. Organization Science, 5(1), 14-37. http://dx.doi.org/10.1287/orsc.5.1.14.

Nonaka, I., \& Takeuchi, H. (1995). The knowledge creation company: how Japanese companies create the dynamics of innovation. Oxford: Oxford University Press.

Nonaka, I., \& Takeuchi, H. (2008). Teoria da criação do conhecimento organizacional: gestão do conhecimento (pp. 54-90). Porto Alegre: The Bookman.

Nonaka, I., Byosiere, P., Borucki, C. C., \& Konno, N. (1994). Organizational knowledge creation theory: a first comprehensive test. International Business Review, 3(4), 337-351. http://dx.doi.org/10.1016/0969-5931(94)90027-2.

Nonaka, I., Takeuchi, H., Rodrigues, A., \& Celeste, P. (1997). Criação de conhecimento na empresa: como as empresas japonesas geram a dinâmica da inovação (A. B. Rodrigues \& P. M. Celeste, trad.). Rio de Janeiro: Campus.

Nonaka, L., Takeuchi, H., \& Umemoto, K. (1996). A theory of organizational knowledge creation. International Journal of Technology Management, 11(7-8), 833-845.

Ortega, N. R. S. (2001). Aplicação da teoria de conjuntos fuzzy a problemas da biomedicina. São Paulo: Instituto de Física, Universidade de São Paulo. http://dx.doi.org/10.11606/T.43.2001.tde-04122013-133237.

Oskouei, A. G. (2013). Investigation of knowledge management based on Nonaka and Tekeuchi model in Mashhad Municipality (Doctoral dissertation). Eastern Mediterranean University, Doğu Akdeniz Üniversitesi, Gazimağusa, North Cyprus.

Sandri, S., \& Correa, C. (1999). Lógica nebulosa (pp. C073-C090). São José dos Campos: V Escola de Redes Neurais, Instituto Tecnológico da Aeronáutica.

Serviço Brasileiro de Apoio às Micro e Pequenas Empresas - SEBRAE. (2018). Critérios de classificação de empresas: MEl-ME-EPP. São Paulo.

Soo, C., Devinney, T., Midgley, D., \& Deering, A. (2002). Knowledge management: philosophy, processes, and pitfalls. California management review. 44(4),129-150.

Tan, R. R., \& Cruz, D. E. (2004). Synthesis of robust water reuse networks for single-component retrofit problems using symmetric fuzzy linear programming. Computers \& Chemical Engineering, 28(12), 2547-2551. http://dx.doi.org/10.1016/j.compchemeng.2004.06.016. 
Tatto, L., \& Bordin, R. A. (2016). Filosofia e Gestão do Conhecimento: um estudo do conhecimento na perspectiva de Nonaka e Takeuchi. Cadernos EBAPE.BR, 14(2), 340350. http://dx.doi.org/10.1590/1679-395141463.

Zadeh, L. A. (1965). Fuzzy sets. Information and Control, 8(3), 338-353. http://dx.doi.org/10.1016/S0019-9958(65)90241-X. 